\title{
COMPLEXITY OF GOVERNANCE STRUCTURES: TAXONOMY OF GOVERNANCE STRUCTURE MODELS USED BY CZECH NATIONAL SPORT ORGANIZATIONS
}

\section{Pavel Král}

\begin{abstract}
Most of the research on nonprofit governance is predominantly focused on board while the complexity of governance structure is overlooked. This study examines governance structure models of Czech national sport organizations (NSOs) as a representative of nonprofit sector. Qualitative research design was employed and document analysis was conducted. Results reveal substantially higher diversity in complexity in governance structure of NSOs in comparison to literature and the results lead to development of taxonomy of governance models of NSOs. Two grounds of the diversity were analysed. First, governance structure models are influenced by continental (two-tier) corporate governance model and Anglo-Saxon (one-tier) governance model. Second, governance structure models vary in number of electoral levels between an individual member and an NSO general meeting. The developed models are discussed and links to structural variables analysed.
\end{abstract}

\section{Key words}

governance structure, structure complexity, two-tier governance, national sport organizations, governance model, strong executive

\section{Introduction and research questions}

Governance research attracts attention of researchers both in corporate and in nonprofit sector and the importance of governance issues is perceived in sport management as well. For example, "Governance of sport(s)" is one of the integral topical sessions of European Association of Sport Management Conference. Governance research is predominantly focused on board (Cornforth, 2012, Speckbacher, 2008). Although board is a central element of good governance acknowledged by scholars (Brown, 2005, Ferkins and Shilbury, 2012, Ferkins, Shilbury and McDonald, 2009, Hoye and Cuskelly, 2007, Inglis, 1997, Yeh and Taylor, 2008) and by codes of good governance (Australian Sports Commission, 2005, Sport and Recreation Alliance, 2011), other aspects of nonprofit governance have been overlooked (Cornforth, 2012). One of the overlooked aspects is governance structure of sport organizations. As Ferkins and Shilbury (2010) conclude, governance structure is an under-researched area not only in sport but in nonprofit sector generally. Especially, there is a dearth of studies on designs of governance structure.

The National sport organizations (NSOs) play a significant role for sport in every country. They are the highest authorities representing any particular sport in their countries with large impact. For example, 73 NSOs associated with Czech Sport Association in the Czech Republic have membership almost 1.5 million (Czech Sport Association, 2013a) what makes over 15\% of Czech population. NSOs are responsible for the rules of a particular sport, state sport representation, redistribution of public resources to sport, and the development of sport. The role 
of NSOs slightly differs in particular countries but their governance structure is the same in all countries (Hums and MacLean, 2009). Moreover, NSOs are an example of dispersed or mutual ownership which is typical for nonprofit sector and also for some professional sport clubs (Ward, Scanlon and Hines, 2012). For this reasons, NSOs can be perceived as an appropriate representative on nonprofit sector.

Governance structure of nonprofit organizations is generally described in accordance with Anglo-Saxon governance model and the same model is recommended for sport organizations. Governance structure of a nonprofit sport organization is considered as a system of the general meeting or the Council, the board and one or more sub-committees (Hoye and Cuskelly, 2007). Having the legal form of "citizen's associations", Czech NSOs are basically governed by the law which was changed last year. Previously citizen's associations had been governed by the Act on Association of Citizens 83/1990. Now, citizen's associations are obliged to change the legal form to "societies" and they are regulated by a particular part of the Civil Code 89/2012. However, the impact of the change is rather of formal consequences. The governance structure has not been regulated very strictly and there are only two compulsory bodies of governance structure: a statutory body (which can be interpreted as board) and a collective body (which can be interpreted as a general meeting). Moreover, it is even possible that these two bodies may be represented by a single body with all powers assigned (Czech Olympic Committee, 2013) and hence, such regulation allows cases of governance duality which is generally considered as unwanted (Elsayed, 2007). Given these points, the governance structure is fully at NSOs discretion and is influenced by nonprofit and corporate governance models.

The objective of the paper is to analyse complexity of governance structure of Czech NSOs, to develop the taxonomy of governance structure models employed by Czech NSOs, and to identify cases where the model of governance structure does not comply with the principles of good governance. This objective is analysed in accordance with elementary dimension of governance structure: horizontal and vertical complexity (Slack and Parent, 2006). Horizontal complexity is used to analyse reflection of governance systems (Anglo-Saxon or continental) into implementation of one-tier or two-tier models. Vertical complexity of NSOs' governance structure derives numbers of electoral levels between an individual member of a particular NSO and the general meeting of the NSO. Structural determinants linked to the governance model are examined next. In addition, cases where governance is not in correspondence with principles of good governance are identified.

\section{Governance structure of NSOs}

Despite the lack of studies has been noticed in many papers, there has not been done much research in the area of governance structure. The most significant work was done in Canada where Canadian NSOs went through the transformation from amateur to professional organizations. Frisby (1986) concluded that numbers of paid staff and numbers of special committees were positively correlated with ability to acquire financial resources, particularly government subsidies. Or generally, more complex the NSOs were larger and acquired more financial resources. However, the causality is unclear. Kikulis et al. (1992) developed a structural design archetypes based on cultural values and organizational structure. They identified three elementary archetypes. First, kitchen table archetype is based on non-formal roles and on interest and loyalty of volunteer staff, few rules, little planning and decision-making based on volunteers. Boardroom archetype has more committees and rules, an organization may be 
operated by professional staff but still, decisions are made by volunteer board. Third archetype is Executive office with many formal roles, rules and programs and the decisions are made by professional staff. Again, complexity was linked to size and professionalism. Recent studies on governance structure of NSOs do not deal with governance structure models but focus its attention on compliance of governance with codes of good governance (Chappelet and Mrkonjic, 2013, Mrkonjic, 2013) or on particular principles such democracy (Enjolras and Waldahl, 2010). This paper covers the gap in knowledge of NSO and nonprofit governance, particularly through examination of elements of organizational structure.

There is no universal framework how to analyse or describe governance structure. In general, governance structure is a part of organizational structure and thus, elementary dimension of organizational structure may be applied. Organizational structure generally analysed or described through elementary three dimensions: complexity, centralization and formalization (Daft, 2010, Robbins and Coulter, 2004, Slack and Parent, 2006). The design of governance structure can be described through the dimension of complexity. Complexity is the most apparent, yet least researched feature of any organizational structure. "Complexity is concerned with the extent to which a sport organization is differentiated" (Slack and Parent, 2006, p. 60) and complexity may occur horizontally and vertically.

Horizontal complexity refers to task differentiation and departmentalization. The difference between one-tier and two-tier governance model can be described along with horizontal complexity. Governance in the Czech Republic has developed under influence of two governance models. The first system is two-tier governance model (or sometimes dual board system) which is characterized by separation of the supervisory board and the executive board (Jungmann, 2006). The two-tier model is traditionally employed in Germany, and some European countries are influenced by this model (e.g. Netherlands, Austria, Finland and Denmark). Corporate governance in the Czech Republic is based on the continental model of corporate governance including two-tier board system (Klírová, 2001, Malý, Theodor and Peklo, 2002, Rủčková, 2008). The two-tier governance model is quite rare in nonprofit organizations and the research on two-tier governance system is very limited. Two-tier governance model is used by Taiwanese NSOs and the impact was examined by Yeh, Taylor and Hoye (2009). They concluded that two-tier governance model helps to distinguish managerial functions of the executive board from monitoring functions of the supervisory board. In their later study (Yeh, Hoye and Taylor, 2011), they revealed that boards roles are linked to the strategic orientation of such organizations.

Vertical complexity refers to number of levels in an organization. Higher vertical complexity is usually prevalent at larger organizations and the more complex is the organization, the more problems with communication, coordination and supervision may occur (Slack and Parent, 2006). Research confirms that the vertical complexity is linked with professionalism of the management (Kikulis, 2000) and vertical complexity grows together size of an organization (Amis, Slack and Hinings, 2002, Kikulis et al., 1989). Also the growing probability of a conflict in an organization caused by higher complexity was confirmed (Amis, Slack and Berrett, 1995). All previous studies were conducted during the transformation in Canada in 1990s, and thus the transformation of sport in the Czech Republic makes an opportunity to revise these conclusions or, to bring new findings.

The model of governance structure is vital because of the principal - agent problem. Principal is usually represented by members in NSOs, and agent is a board member or an appointed 
executive member. Thus, NSOs are distinguished by dispersed form of ownership. According to Jensen and Fuller (2002) members should hold the rights to ratify initiatives and key decisions of managers (ratification rights) and the rights to measure, evaluate, and reward or punish performance of managers (monitoring rights). Such situation is considered to be optimal and termed as effective governance while the loss of monitoring rights is termed as strong executive (Král et al., 2012). The case of strong executive may lead to misuse of power and was cause of corporate scandals such Enron or WorldCom which drew attention to corporate governance (Schnackenberg and Tomlinson, 2014). Thus, good governance structure can prevent from corporate scandals and from misuse of power.

Even Czech sport has encountered the situation where strong executive led to a corporate scandal and this scandal was connected with Czech NSOs, specifically with a company governed by Czech NSOs. Czech NSOs had been owners of the largest lottery company Sazka until 2011 when Sazka was declared bankrupt and subsequently taken over by private investors. Thus, Czech NSOs lost about 13\% of its revenues and the bankruptcy of Sazka is considered to be the most significant milestone for Czech sport in the last 20 years (Numerato and Flemr, 2013). Analysis of the causes of the bankruptcy was difficult because of low governance transparency of Sazka that disabled to get relevant governance documents. However, strong executive was revealed as a main cause behind. The board failed to ensure top-level control mechanism, and the CEO Aleš Hušák dominated not only the company but also commanded the board. For example, members of board had no notion of CEO's remuneration which was obviously excessive, even in comparison with the best top managers' remuneration (Aon Hewitt, 2011, Král, 2012). As a result, Czech NSOs lost the cash cow securing revenues over 40 million EUR because they were not able to express their monitoring rights.

Not only large organizations encounter strong executive. On the other side of the spectrum with regards to size of an organization, there are grassroots organizations. Grassroots organizations are defined as "essentially local-scoped and voluntary organizations" (Smith, 2000, p. 7) and they are represented by single sport clubs. Previous research in the Czech Republic brought evidence that grassroots sport organizations are endangered by strong executive as well. The cause was identified rather in lack of interest of club members in governance than in governance structure itself (Král et al., 2010). So far, there was little research done either on general governance system or on grassroots association, and there is a gap in knowledge of governance of NSOs at all. Thus, this paper sheds light on governance of individual NSOs.

\section{Methodology}

Qualitative research design was employed what reflects exploratory nature of the research and nature of data required (Edwards and Skinner, 2009, Patton, 2002, Tracy, 2013). The research sample comprised NSOs affiliated with the Czech Union of Sport (CUS). CUS is the largest governing body in the Czech Republic and it associates 74 NSOs what represents the majority of Czech NSOs. Particularly, CUS associates 35 Olympic and 39 non-Olympic sport NSOs. (Note: It is important to mention that the name of this umbrella association had been formerly Czech Sport Association (CSA) and the name was changed during the research process. Thus, the links contain CSA in cases where the data were acquired from the former CSA documents while CUS is used as a general name for the umbrella association). Five of the NSOs were excluded from the research sample because they did not meet the criteria of a standard NSO (Hums and MacLean, 2009). Mountain Rescue Association of the Czech Republic, Czech Association of Recreational 
Sport, Czech University Sport Association and Union of Handicapped Athletes did not meet the criteria of representing an individual sport or group of sports. Another excluded NSO was Czech Yoga Association which does not organize any competitions. Two other NSOs were excluded because they became members during the research process (Czech Cheer Association and Czech Association for Sport for All). In the end, the sample consisted of 67 NSOs. These 67 NSOs associated more than 1.4 million registered members.

Secondary data were collected from the official web pages of the NSOs. The list of the NSOs was acquired through CSA webpages(Czech Sport Association, 2013b). Secondary data comprised all available NSOs governance documents such statutes, general meeting reports, annual reports, board and executive member lists, financial documents and strategic documents. Because of heterogeneous structure of the webpages and different format of the documents, the web pages were scrutinized manually in all their sections. Other sources of data comprised annual report of CSA (Czech Sport Association, 2013a) to acquire official NSO membership, numbers of affiliated clubs, and official rankings of the Ministry of Youth, Education and Sport (Ministry of Education Youth and Sport, 2010) to get overall significance of NSOs. The overall significance incorporates apart from other things sport success, competition, popularity and membership and divides NSOs into three groups.

Data analysis was carried out in three steps. First of all, governance documents were examined and governance structure of each NSO was analysed. The purpose was to identify the governance bodies, examine their authorities, and analyse the relations among them to describe the governance structure of the NSOs. Subsequently, selected variables were developed and operationalized for development of the taxonomy and further statistical analysis. The horizontal complexity of governance structure was expressed through binomial variable (one-tier or two-tier board). The vertical complexity derived nominal variable based on the number of electoral governance levels. To demonstrate the coding of the variable, generally described governance model has a single electoral level because members of a club elect their representative who attends the general meeting of entire NSO. In the case where elected representatives of clubs attends general meeting of regional NSO first, and then these representatives elect their representatives who attends the general meeting of particular NSO, there are two electoral levels. Finally, the taxonomy of governance models was developed upon those findings and statistical analysis was carried out to search for links between variables. The analysis was conducted in SPSS and used statistical hypothesis testing.

\section{Results}

Data were acquired from 52 of 67 NSOs what makes $78 \%$ response rate. The sample comprised 31 Olympic NSOs and 21 NSOs representing non-Olympic sports what gives appropriate representation of the population. The average membership of the sample NSOs was 25,018 members, respectively 14,944 members excluding the Football Association of the Czech Republic which itself has over $30 \%$ of registered members all NSOs, and thus makes an extreme case regarding the membership. This fact was considered when testing hypotheses. The average membership of $15 \mathrm{NSO}$ whose documents were not available and thus were excluded from the research sample was 4,437 members what makes the results biased towards the NSOs with higher membership $(\mathrm{t}=2,144 ; \mathrm{p}=0,036)$. However, the sample comprises NSOs with very low membership as well (e. g. Czech Republic Luge Sport with 450 members) and it is likely that the sample represents all possible governance models. When identifying governance bod- 
ies, it was necessary to analyse authorities of particular governing bodies since the terminology is not very consistent. The highest governing body is called general meeting in 30 of 52 NSOs. However, the main difference from remaining 22 NSOs is only in terminology (such as conference, presidium, parliament, assembly or congress) and the authorities of the highest governing body are very similar. Thus, the highest governing body is handled as general meeting at all NSOs. Competencies of general meetings at all NSOs comprise approval of statutes, affiliation and expelling clubs and members, approval of annual reports, financial reports and voting statutory bodies. The meeting period of general meeting ranges from six months (Czech Archery Association) up to four years (nine NSOs). The average meeting period is 1.72 years. The second common governing body is a statutory body which manage the operations of an NSO. Again, the terminology is not consistent but upon examination of authorities, it is possible to use a term board. The number of board members varies from three to fourteen with average of seven. The third governing body was a kind of supervisory board which was identified in ten NSOs. The responsibilities of such body are generally reduced from responsibilities of general meeting and the role is mostly in monitoring the board activities, approval of annual reports and approval of financial reports.

The purpose of the horizontal complexity analysis was to identify implementation one or two-tier models and search for structural determinants linked to the one-tier or two-tier governance model. Forty-two NSOs uses one-tier governance model while governance structure of 10 NSOs comprise another governance body in addition to general meeting and board. The only NSO (The Association of Czech Skiers) of those 10 NSOs could be classified as a typical continental model with supervisory board and executive board. The remaining nine NSOs can be classified as "The Czech governance model according to Anglo-Saxon pattern" (Rǔčková, 2008, pp. 29-30). The additional governing body in these NSOs takes some responsibilities of the general meeting and makes important decisions between the regular general meetings. The additionally governing body meetings period is usually six months or a year what helps to bridge longer general meeting period.

Analysis of structural differences between NSOs using one-tier or two-tier governance models revealed that two-tier governance model is employed by NSOs with more affiliated clubs $(\mathrm{t}=2.063 ; \mathrm{p}=.044)$, with more paid staff $(\mathrm{t}=4.303 ; \mathrm{p}=.000)$ and two-tier system is employed by more significant NSOs according to Ministry of Education, Youth and Sport assessment $\left(\chi^{2}=6,642 ; p=0,036\right)$ (Ministry of Education Youth and Sport, 2010). Another difference between NSOs using one-tier and two-tier governance model was identified in the period of general meetings. The period of general meeting of NSOs with one-tier governance system is 1.57 years and the period of NSOs with two-tier governance system is 2.40 years what makes the period significantly different $(\mathrm{t}=2.190 ; \mathrm{p}=.033)$.

The vertical complexity analysis was focused on number of electoral levels between an individual member of a particular NSO and the general meeting of the NSO. In other words, this dimension states how many levels of election of representatives are between an individual member and general meeting of an NSO. The governance structure models were classified into four typical groups and four models were derived upon the findings. The developed taxonomy consists of four models: the direct model, the club model, the regional model and the mixed model. The taxonomy is pictured on figure one. 


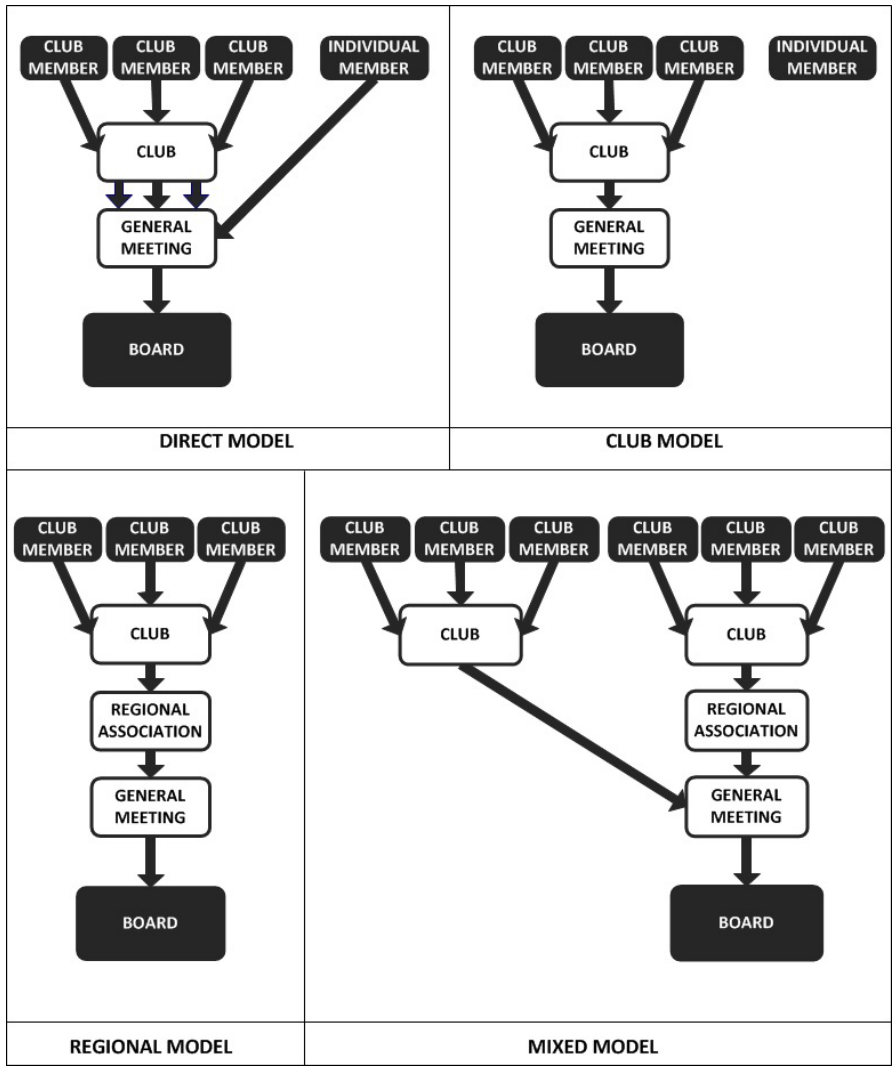

Fig. 1: Taxonomy of governance structure models according to number of decision-making levels

The first model is the direct model. In the direct model, each individual member has the right to vote at general meeting and a member can either attend general meeting personally or delegate his or her voting right to a club representative (who has a number of votes corresponding to a number of members who had delegated him or her). This model is used by two NSOs (the Czech Mountaineering Association (CHS) and the Czech Federation of Bodybuilding and Fitness (SKFCR)). Surprisingly, these are NSOs with membership higher than median (CHS 14,372 and SKFCR 8,762). Attendance at general meeting of The CHS was 25\% of all members what points at interest of the members in governance.

In the club model, the right to vote at NSO general meeting is delegated to a representative of a club affiliated with the NSO. This is the prevalent model employed by 27 NSO what makes $52 \%$ of the sample. Differences were identified in rules of nominations of delegates for general meeting. Most NSOs have a very simple rule and each club can nominate a single delegate (e. g. the Czech Golf Federation, the Czech Gymnastic Federation). Other NSOs determine the number of delegates according to membership (e. g. the Czech Archery Association). 
Moreover, as the reaction to problems with inflated membership, some NSOs determine the number of delegates from members who had paid the membership fee on time (e.g. the Czech Volleyball Federation) or even from members participating in competitions (e.g. the Czech Modern Pentathlon Association). In some cases, the numbers of delegates are determined and approved at general meeting (e.g. Czech Squash Association) or at board meeting (the Czech Korfball Federation). In sum, the club model is the most applied model with differences in determining the proportion of delegates of general meeting.

Third model adds one or more electoral level between a club and NSO general meeting, usually in the form of general meeting of district of regional NSO association. In such case, delegates of the club attend a regional general meeting where they elect delegates for a general meeting. Sometimes there are two additional electoral levels where district general meeting comes first and regional general meeting comes next or, there are general meetings of independent sections instead of general meetings of regional associations. Direct interaction between an individual member and a delegate of general meeting is not likely. Ten NSOs use this model. Although there are differences in determining numbers of delegates for a general meeting, the main feature of the model is a direct hierarchy of the electoral levels.

The mixed model combines attributes of previous models and it is applied by 13 NSOs of the sample. This model is generally based on regional model and frequently assigns extra electoral rights either to large clubs or to members of governing bodies. Thus, a kind of prioritization of members is made to ensure extra electoral right to most impacted members. The most sophisticated mixed model was revealed at the Football Association of the Czech Republic (FACR). The FACR general meeting comprise representatives of all clubs from the three highest leagues (66), elected representatives of the fourth league clubs (35 delegates of 80 clubs), representatives of regional associations (14) and representatives of district associations (87). The mixed model is also used by some NSOs with independent sections such as Czech Canoe Union where delegates for the general meeting of the entire NSO are nominated at general meetings of individual sections which vary in the rules for nominations.

Two examples where governance structure design does not comply with the good governance principles were identified. Both examples represent cases of strong executive but each of them is of unique nature. Governance model of the Czech Cycling Federation (CCF) allows the executive members to be in a majority on general meetings. The proportion of votes at general meeting assigns 28 votes to regional delegates, 28 votes to representatives of committees of 7 main disciplines (such as road, MTB, BMX, etc.) and a single vote to the president. However, there are no rules how to elect or appoint the representatives of the committees. Upon a thorough examination of the statutes (part X - Authorities of the president and part XII - Committees), the authority to appoint the representatives may be assigned to the president. Thus, the president can have majority together with the representatives he appoints. Follow-up interviews with three members of the CCF confirm the exclusion of the members from decision-making and thus strong executive case.

Another case of strong executive represents the governance model of the Czech Tennis Federation (CTF) because of exceptional authorities of a president. A president nominates members of executive board who are approved by supervisory board subsequently. If a member is not approved by supervisory board the president should nominate another candidate. Thus, the president influences the board composition very strongly and supervisory board can only put a veto on undesirable candidate. Czech tennis has reached historical success in recent years 
(victory both in Davis Cup and Fed Cup) and paradoxically, this model is linked with high performance of the organization.

Finally, the statistical analysis was used to reveal links between the operationalized governance variables (horizontal complexity - governance tiers, and vertical complexity - governance levels in the table 1). Overall, NSOs with more members and more affiliated clubs have governance structure with more electoral levels. On the other hand, two-tier governance structure is not linked with membership but it is linked with NSO significance (combining sport success, competition and overall impact of the sport). On the other hand, there was no link to total revenues which approximate the size of an NSO as well. The results are presented in table 1 .

Governance tiers

Governance levels

\begin{tabular}{lcc}
\hline Membership & & $* * *$ \\
Affiliated clubs & $* *$ & $* * *$ \\
Number of staff & \\
Total revenues & $* * *$ \\
NSO significance & \\
$* * * \mathrm{p} \leq 0,01$ & \\
$* * * \mathrm{p} \leq 0,05$ & \\
$* \quad \mathrm{p} \leq 0,1$ & \\
\hline
\end{tabular}

Tab. 1: Relations between governance and structural variables

\section{Discussion, limitations and conclusions}

The confrontation of Anglo-Saxon one-tier governance model with continental two-tier governance model reflects in diversity of bodies comprised in governance structure of Czech NSOs. Generally, two-tier governance system is used by larger NSOs but the main reason for two-tier governance model is perceived ability to ensure monitoring of the board when the period of general meetings is longer than a year. In such case, the additional governance body takes the necessary responsibility for the monitoring of the board and for decisions which must be done at least once in a year (e. g. approval of annual report, income statement, budget and strategic plan). Fourteen of forty-two NSOs using one-tier model have the period of general meetings longer than a year (even four years) and thus the monitoring of board activities is not sufficient. Czech NSOs admit the problem to secure sufficient attendance at general meeting and thus, "The Czech governance model" with an additional governance body is advisable for all NSOs with longer period of general meetings.

The second aspect of governance structure assessment brought the key results of the paper because the number of decision making levels in governance structure had not been examined yet. Generally, governance structure is usually described as the club model with just one electoral level between a member and general meeting (Hoye and Cuskelly, 2007, National Council for Voluntary Organisations, 2005). Nevertheless, $48 \%$ of NSOs have different governance 
structure. Taxonomy of governance structure models was developed and the taxonomy identified three new models in addition to the club model which is generally used to describe nonprofit or NSO governance structure. The first of new models is the direct model. The direct model enables the best interaction between an individual member and NSO general meeting. Attendance at the Czech Mountaineering Association general meeting over 25\% of all members indicates high interest in governance which is clearly higher than in all other systems. The interest is probably encouraged by the direct ability to influence general meeting decision. The other two new models add one or more electoral level what has not been described in relevant literature yet.

This paper aims to open the discussion on governance structure and it brings several options for future research. Firstly, the results indicate that the direct model is linked to higher attendance at general meetings and it may be interpreted as higher interest in governance. Minutes from general meetings indicate that many NSOs are struggling to reach quorum what confirms previous findings on lack of interest in governance arising from grassroots organizations. Further research on democracy in governance of NSO can focus on board - general meeting interaction and stakeholders' perception of ability to influence general meeting decisions. Such research may reveal how to encourage stakeholders to pay more attention to governance and may provide an answer how to raise interest in governance. Secondly, results did not find any link between the form of governance structure and effectiveness. Surprisingly, we the study identified the example of strong executive connected with high effectiveness of Czech Tennis Federation. On the other hand, executive control in hands of those at the top, leaving the membership with little real power is likely to undermine organizational legitimacy (Enjolras and Waldahl, 2010) and strong dependency on a single person brings high risk for any organization. Further studies on the link between governance structure and NSO effectiveness or just board effectiveness could help to broaden under-researched topic of mechanisms of effectiveness.

This study has two limitations. Firstly, governance document were available from 52 of 67 NSO and thus the distribution of the models can vary. Because the documents were acquired rather from larger NSOs there can be a bias in distribution towards more complex governance structure models. However, it is not likely that smaller NSOs would affect the developed taxonomy. Second limitation is perceived in low transparency of Czech NSOs which prevented the research from identifying the links between governance structure and effectiveness of NSOs. Therefore it is a recommended topic for further research.

In conclusion, the study reveals that the governance structure models employed by Czech NSOs are diverse of what can be found in the literature and codes of good governance applicable for nonprofit sector and, particularly codes for sport organizations. Two main grounds of such diversity were identified. Firstly, Anglo-Saxon one-tier governance model reflected in codes of good governance for nonprofit and sport organizations is confronted with continental two-tier governance model used in the Czech Republic by corporate sector. Hence, about one fifth of NSOs employ a governance model which is inspired by two-tier governance model. Those are generally larger NSOs and they use the advantages of the two-tier governance model to have longer period of general meetings. Secondly, NSOs governance structure models differ in number of decision making levels between an individual member and an NSO general meeting. This aspect led to development of taxonomy with four elementary governance structure models: the direct model, the club model, the regional model, and the mixed model. 
Moreover, two exceptions inherently enforcing strong executive were identified. The governance model is critical in ability of individual members to influence general meeting decisions. Thus, the more complex is the governance structure, the higher attention to communication and transparency is advisable because such complexity creates conditions for misuse of power.

\section{Bibliography}

Act on Association of Citizens, Act on Association of Citizens, 83/1990.

Amis, J., Slack, T. \& Berrett, T., 1995. The structural antecedents of conflict in voluntary sport organizations. Leisure Studies, Vol. 14, No. 1, 1-16.

Amis, J., Slack, T. \& Hinings, C. R., 2002. Values and organizational change. The Journal of Applied Behavioral Science, Vol. 38, No. 4, 436.

Aon Hewitt, 2011. Studie celkového odměňování [Study of overall remuneration]. Prague: Aon Hewitt.

Australian Sports Commission, 2005. Governing sport: The role of board, a good practice guide for sporting organisations. Canberra, Australia: Australian Sports Commission.

Brown, W. A., 2005. Exploring the association between board and organizational performance in nonprofit organizations. Nonprofit Management and Leadership, Vol. 15, No. 3, 317-339.

Civil Code 89/2012, Civil Code, 89/2012.

Cornforth, C., 2012. Nonprofit governance research: Limitations of the focus on boards and suggestions for new directions. Nonprofit and Voluntary Sector Quarterly, Vol. 41, No. 6, 1116-1135.

Czech Olympic Committee, 2013. Právní úprava spolků dle nového občanského zákoníku [Ancillary legislation of societies according to new Civil Code] [Online]. Praha: Legislation committee of Czech Olympic Committee. Available: http://www.cuscz.cz/files/475ZmZ.pdf [Accessed 10.1.2014.

Czech Sport Association, 2013a. Ročenka ČSTV [Annual report of CSA] [Online]. Praha: Czech Sport Association. Available: http://www.cuscz.cz/o-nas/rocenka-cus/rocenka.html [Accessed 1.4.2013.

Czech Sport Association, 2013b. Sdružené sportovní svazy v ČSTV [Associated National Sport Organizations in CSA] [Online]. Prague: Czech Sport Association. Available: http://www.cstv.cz/ sdruzene.htm [Accessed 10.3.2013 2013].

Daft, R. L., 2010. Organization theory and design, Mason, OH: South-Western Cengage Learning.

Edwards, A. \& Skinner, J., 2009. Qualitative research in sport management, Sydney: ButterworthHeinemann.

Elsayed, K., 2007. Does CEO duality really affect corporate performance? Corporate Governance: An International Review, Vol. 15, No. 6, 1203-1214.

Enjolras, B. \& Waldahl, R. H., 2010. Democratic governance and oligarchy in voluntary sport organizations: The case of the Norwegian Olympic Committee and Confederation of Sports. European Sport Management Quarterly, Vol. 10, No. 2, 215-239.

Ferkins, L. \& Shilbury, D., 2010. Developing board strategic capability in sport organisations: The national-regional governing relationship. Sport Management Review, Vol. 13, No. 3, 235-254.

Ferkins, L. \& Shilbury, D., 2012. Good boards are strategic: What does that mean for sport governance? Journal of Sport Management, Vol. 26, No. 1, 67-80.

Ferkins, L., Shilbury, D. \& Mcdonald, G., 2009. Board involvement in strategy: Advancing the governance of sport organizations. Journal of Sport Management, Vol. 23, No. 3, 245-277.

Frisby, W., 1986. The organizational structure and effectiveness of voluntary organizations: The case of Canadian national sport governing bodies. Journal of Park and Recreation Administration, Vol. 4, No. 3, 61-74.

Hoye, R. \& Cuskelly, G., 2007. Sport governance, Oxford, U.K.: Elsevier.

Hums, M. A. \& Maclean, J. C., 2009. Governance and policy in sport organizations, Scottsdale, AZ: Holcomb Hattaway. 375. 
Chappelet, J.-L. \& Mrkonjic, M., 2013. Basic inators for better governance in international sport (BIBGIS): An assessment tool for international sport governing bodies. IDHEAP Working Paper.

Inglis, S., 1997. Roles of the Board in Amateur Sport Organizations. Journal of Sport Management [JSM], Vol. 11, No. 2, 160-176.

Jensen, M. C. \& Fuller, J., 2002. What's a director to do? Harvard NOM Research Paper, Vol. 52, No. 2, $1-12$.

Jungmann, C., 2006. The effectiveness of corporate governance in one-tier and two-tier board systems - Evidence from the UK and Germany-. European Company and Financial Law Review, Vol. 3, No. 4, 426-474.

Kikulis, L. M., 2000. Continuity and change in governance and decision making in national sport organizations: Institutional explanations. Journal of Sport Management, Vol. 14, No. 4, 293-320.

Kikulis, L. M., Slack, T. \& Hinings, B., 1992. Institutionally specific design archetypes: A framework for understanding change in national sport organizations. International Review for the Sociology of Sport, Vol. 27, No. 4, 343-368.

Kikulis, L. M., Slack, T., Hinings, B. \& Zimmermann, A., 1989. A structural taxonomy of amateur sport organizations. Journal of Sport Management, Vol. 3, No. 2, 129-150.

Klírová, J., 2001. Corporate Governance: Správa a řízení obchodních společností [Corporate governance], Praha: Management Press.

Král, P., 2012. How Czech sport lost a cash cow: A Case study of governance failure leading to crisis of Czech sport. In: MANAGEMENT, E. A. F. S. (ed.) Sport between business and civil society. Aalborg, Denmark.

Král, P., Pirožek, P., Štrach, P. \& Zdeňková, K., 2010. Leisure sport governance principles: Czech cycling associations. In: MANAGEMENT, E. A. F. S. (ed.) 18th EASM Conference. Prague.

Král, P., Tripes, S., Pirožek, P. \& Pudil, P., Two-dimensional governance matrix: A framework to evaluate organizational governance. 8th European Conference on Management Leadership and Governance, 2012 Paphos, Cyprus.

Malý, M., Theodor, M. \& Peklo, J., 2002. Rízení a správa společností [Corporate governance], Praha: Oeconomica.

Ministry of Education Youth and Sport, 2010. Zásady programu I. - Sportovní reprezentace České republiky [Principles of Program I - Representation of Czech Republic]. Praha: Ministry of Eduction, Youth and Sport.

Mrkonjic, M., 2013. Measuring the governance of international sport organisations: Democracy, transparency and responsibility as key attributes. The 21st EASM Conference. Sport Management for Quality of Life. Istanbul, Turkey: European Association for Sport Management.

National Council for Voluntary Organisations, 2005. Good governance: A code for the voluntary and community sector. London, UK: National Council for Voluntary Organisation.

Numerato, D. \& Flemr, L., 2013. The Czech Republic. In: O`BOYLE, I. \& BRADBURY, T. (eds.) Sport Governance: International Case Studies. 1st ed. Oxon: UK: Routledge.

Patton, M. Q., 2002. Qualitative research \& evaluation methods, Thousand Oaks, California: Sage Publications.

Robbins, S. P. \& Coulter, M., 2004. Management, Praha: GRADA.

Růčková, P., 2008. Corporate Governance v České republice [Corporate governance in the Czech Republic], Praha: Grada.

Schnackenberg, A. K. \& Tomlinson, E. C., 2014. Organizational Transparency A New Perspective on Managing Trust in Organization-Stakeholder Relationships. Journal of Management.

Slack, T. \& Parent, M. M., 2006. Understanding sport organizations: The application of organization theory, Champaign, IL: Human Kinetics.

Smith, D. H., 2000. Grassroots associations, Thousand Oaks, CA: Sage.

Speckbacher, G., 2008. Nonprofit versus corporate governance: An economic approach. Nonprofit Management and Leadership, Vol. 18, No. 3, 295-320. 
Sport and Recreation Alliance, 2011. Voluntary code of good governance for the sport and recreation sector. London: Sport and Recreation Alliance.

Tracy, S. J., 2013. Qualitative research methods, Malden, MA: Wiley-Blackwell.

Ward, S., Scanlon, T. J. \& Hines, T., 2012. Mutuality ownership form and professional sports: Football. Nonprofit and Voluntary Sector Quarterly, Vol. 42, No. 4, 763-780.

Yeh, C. M., Hoye, R. \& Taylor, T., 2011. Board roles and strategic orientation among Taiwanese nonprofit sport organisations. Managing Leisure, Vol. 16, No. 4, 287-301.

Yeh, C. M. \& Taylor, T., 2008. Issues of governance in sport organisations: A question of board size, structure and roles. World Leisure Journal, Vol. 50, No. 1, 33.

Yeh, C. M., Taylor, T. \& Hoye, R., 2009. Board roles in organisations with a dual board system: Empirical evidence from Taiwanese nonprofit sport organisations. Sport Management Review, Vol. 12, No. 2, 91-100

Pavel Král University of Economics Prague, Faculty of management

kralpa@fm.vse.cz 